\title{
Dal reale al virtuale: quando la tecnologia accorcia le distanze
}

\author{
Chiara Vernizzi \\ Roberto Mazzi
}

Abstract

Nella primavera del 2020, per celebrare i primi Vent'anni dei corsi di studio in Architettura, è stata allestita presso l'Università di Parma una mostra con una selezione di elaborati grafici realizzati dagli studenti nei vari insegnamenti di Disegno. I noti eventi pandemici non hanno consentito l'apertura e la fruizione in presenza della mostra, spingendo a crearne una versione virtuale visitabile da remoto, sfruttando strumenti e tecniche di modellazione e visualizzazione tipici delle finalità progettuali, stavolta piegati a diverse esigenze di rappresentazione dei contenuti, a cui sempre più spesso si ricorre per la diffusione e condivisione del patrimonio culturale.

Tramite la creazione di un sito web, sul quale è stato caricato il modello parametrico digitale dello spazio espositivo, virtualmente allestito con i pannelli esposti nella versione fisica della mostra, è stato possibile ricreare gli spazi e visualizzare le singole tavole, attraverso un virtual tour realizzato utilizzando, tra le altre, la tecnica delle immagini sferiche.

La contingenza negativa dalla quale si è sviluppata la necessità di trovare altre vie di disseminazione degli esiti del lavoro, ha spinto a sperimentare nuove vie di rappresentazione e comunicazione di un allestimento non progettato per essere usufruito in questa modalità. Le tecniche utilizzate hanno tuttavia rivelato le loro potenzialità nell'incrementare la fruizione della mostra senza limiti di tempo e di spazio.

\section{Parole chiave}

esposizione, disegni, modellazione BIM, foto sferiche, virtual tour.

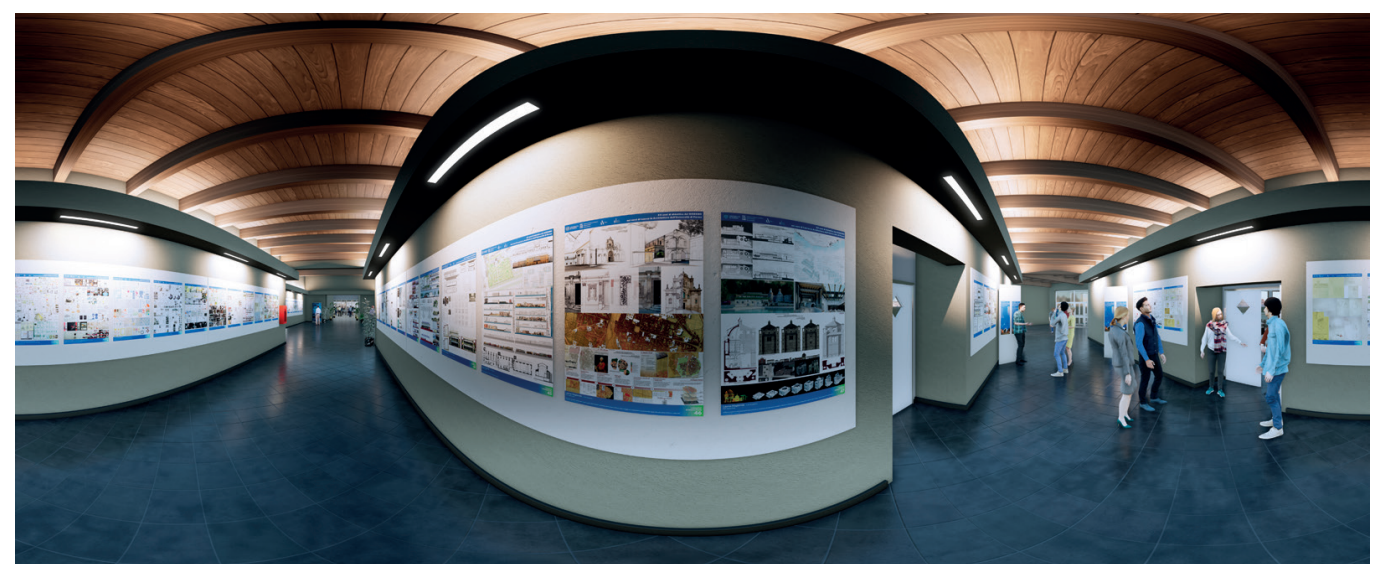




\section{Introduzione}

Nella primavera del 2020, per celebrare il primo ventennale dei corsi di laurea in Architettura presso l'Università di Parma (A.A. 1999/2000 - A.A. 2019/2020), i docenti di Disegno e Rilievo del Dipartimento di Ingegneria e Architettura hanno promosso una mostra volta ad esporre una selezione dei più significativi esempi degli elaborati grafici realizzati, nell'ambito degli insegnamenti dell'area della Rappresentazione, dagli studenti di tutti i corsi di Laurea Triennale e Magistrale in ambito architettonico durante questi vent'anni.

La mostra, patrocinata dall'UID quale testimonianza della connotazione della disciplina all'interno dei corsi di laurea parmensi, era stata allestita presso lo spazio espositivo interno al Plesso Aule delle Scienze nel Campus Universitario di Parma e si sarebbe dovuta inaugurare ai primi di marzo alla presenza del CTS dell'UID, che per l'occasione si sarebbe riunito a Parma.

Come noto, dai primi di marzo del 2020 è scattato il lockdown nazionale conseguente la situazione di emergenza sanitaria e la mostra, anche a causa delle restrizioni successive che vietavano assembramenti, non è mai stata inaugurata ed aperta al pubblico.

Per non vanificare il lavoro svolto e conservare una testimonianza di quanto fatto, si è allora pensato ad altri mezzi: un catalogo della mostra, in primis, ma anche un sito web connesso al libro tramite QR code, che fornisse la possibilità di visionare le tavole esposte attraverso un percorso virtuale interattivo.

Ormai necessariamente sempre più vicini al mondo virtuale e alla fruizione degli eventi online, dei quali soprattutto in questo ultimo anno abbiamo approfondito l'esplorazione delle possibilità, si è infatti pensato di creare un tour virtuale della mostra, che ne consentisse la frequentazione da remoto a più visitatori, senza porre limiti al tempo ed allo spazio della fruizione.

Le tecnologie impiegate nella realizzazione della mostra virtuale, di seguito descritte, rientrano a pieno titolo tra gli strumenti caratteristici della nostra disciplina, con cui solitamente documentiamo l'esistente e rappresentiamo il progetto, ma proprio in virtù della loro versatilità sono risultate adeguate anche nella costruzione di questo percorso (fig. I).

\section{Spazi reali e spazi virtuali}

Realizzare una mostra vuol dire raccontare in modo sintetico le tematiche che si vogliono comunicare. Se tali tematiche sono legate ad un periodo della durata di venti anni, il mezzo che trasporta il messaggio dovrà essere particolarmente efficace. Curare il progetto di una mostra che tratta di tematiche legate alla Rappresentazione e al Disegno nelle sue varie digressioni diviene quindi, nello stesso tempo, strumento comunicativo e messaggio.

La mostra segue un processo evolutivo che ripercorre la traccia lasciata all'interno di un periodo storico in cui le tecniche di rappresentazione del progetto si sono modificate, evo-

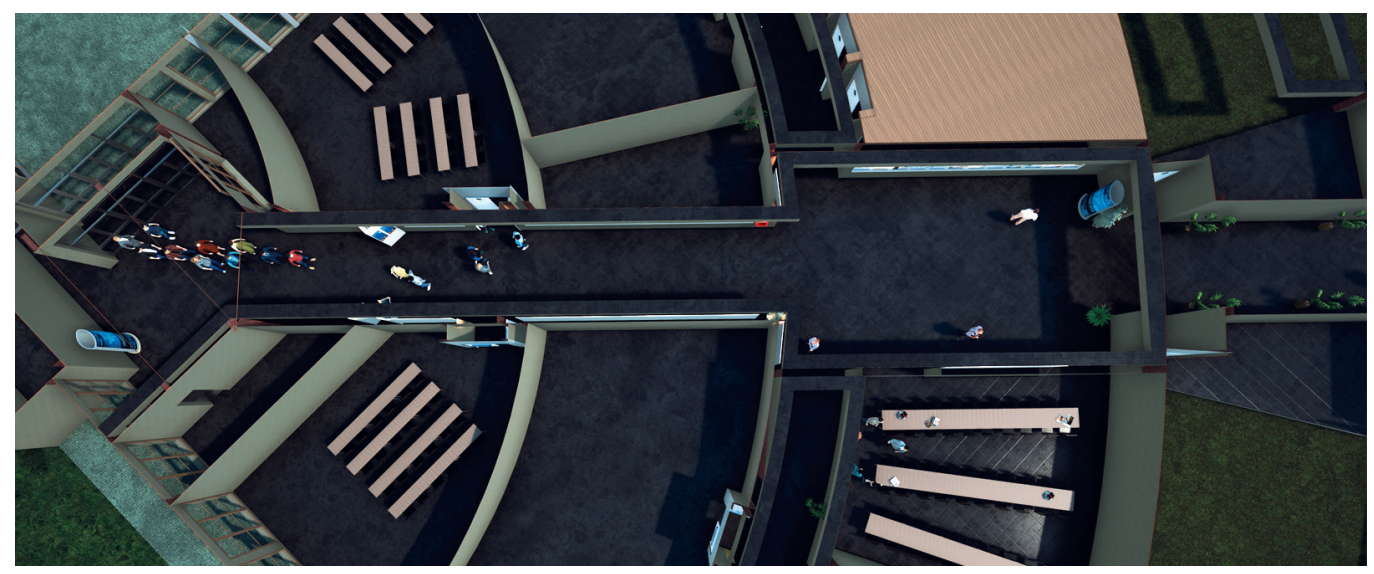


Fig. 2. Atrio centrale Plesso Aule delle Scienze, controcampo dell'ingresso, render.

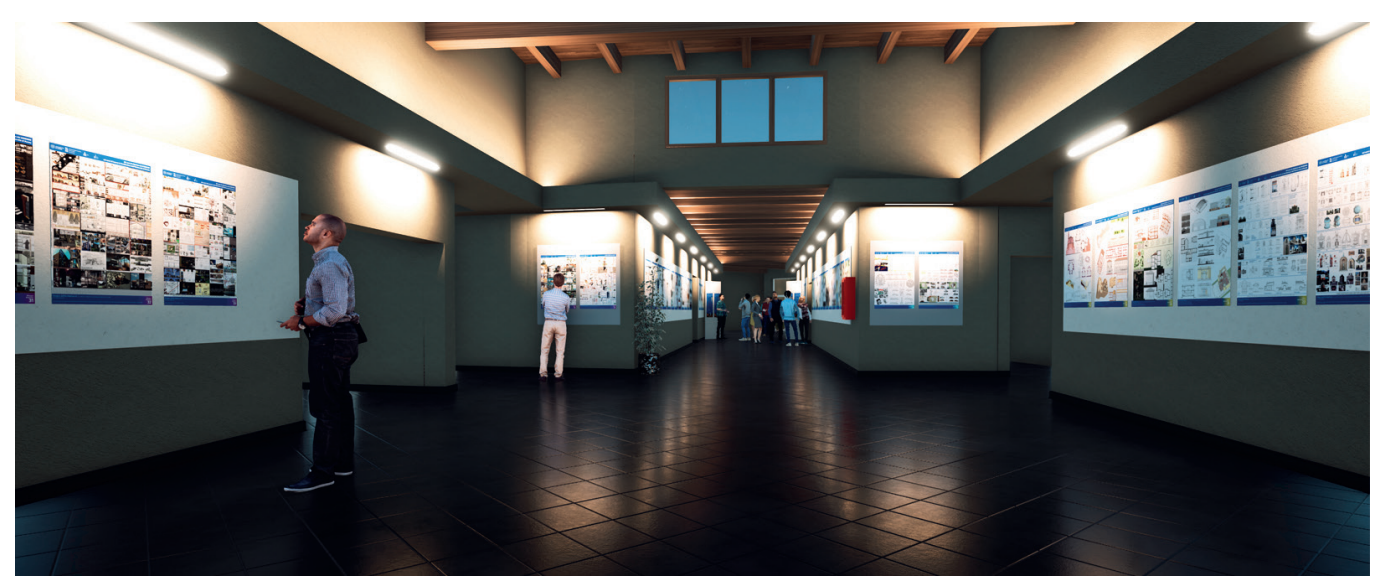

lute, affinate. Se dovessimo descrivere la progressione delle tecniche utilizzate, potremmo rappresentarle con una curva esponenziale. La logica collaborativa data dall'avvento dell'informatica ha fatto in modo che le tecniche della rappresentazione abbiano perso le caratteristiche date dalla mano del disegnatore, dirigendosi verso la riproducibilità data dal mouse. Tali strumenti si sono definiti sempre più, mantenendo la finalità della trasmissione tramite un 'racconto' composto da parole, tratti, concetti ed elaborati. Anche per questa mostra non si è fatta eccezione a questi capisaldi, partendo dal progetto espositivo, concatenato al progetto grafico degli elaborati.

L'approccio comunicativo e di divulgazione dei contenuti della mostra ha dovuto guardare verso direzioni differenti, per le nuove condizioni imposte dal lockdown. Da un'esigenza contingente dettata dalla situazione di emergenza, si è colta l'occasione per sfruttare tecniche note nel campo della progettazione architettonica, applicandole nell'ambito dell'esposizione. I metodi per poter trasportare la mostra 'fuori dalla mostra' potevano essere differenti, come ad esempio una serie di scatti fotografici, un video, etc. Tutte queste ipotesi implicavano la medesima problematica di entrare in un luogo fisico reale a cui era interdetto l'accesso.

Si è quindi scelto di affrontare il percorso che potesse dare soluzione a questo problema, attingendo alle tecniche odierne proprie della comunicazione dei progetti. Nelle giornate successive alla mancata apertura, è stato creato un modello virtuale dello spazio espositivo, incrociando informazioni geometriche recuperate da planimetrie e fotografie degli ambienti. II modello è stato realizzato con lo scopo di mostrare i cinquanta elaborati grafici creati ed esposti all'interno del corridoio centrale del plesso (fig. 2).

Il gemello digitale della mostra è stato realizzato con le metodologie proprie del BIM (fig. 3), inserendo all'interno dello spazio (architettonico) virtuale così ricostruito gli oggetti del-

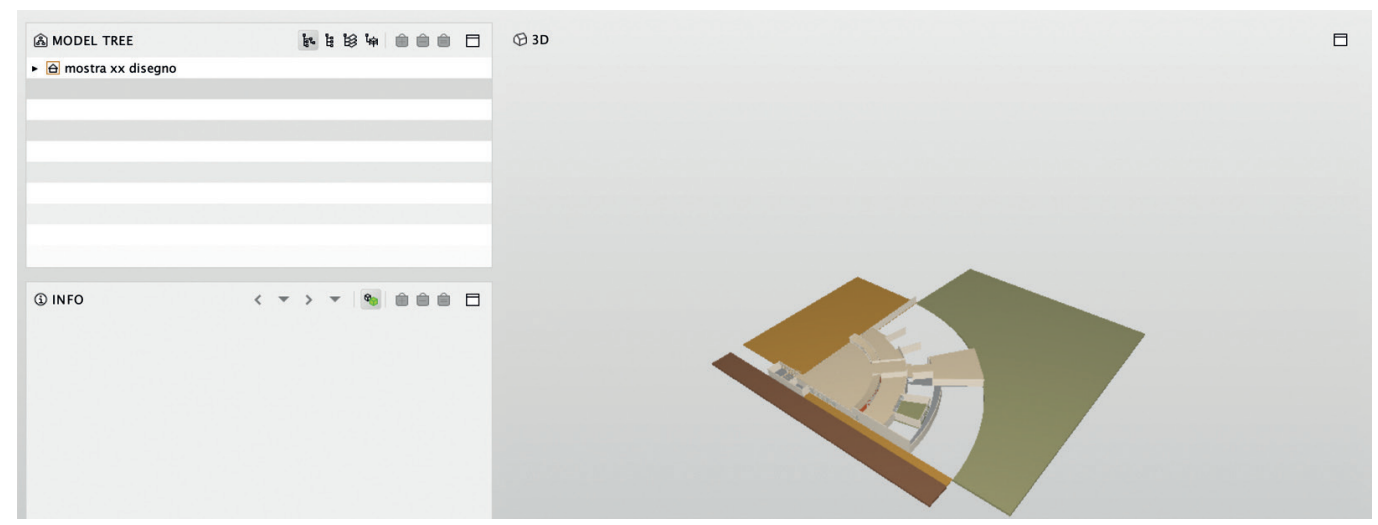


Fig. 4. Modello BIM, vista corridoio centrale, risultato esportazione modello in formato IFC $2 \times 3$

Fig. 5. Modello BIM, informazioni esportate nel modello in formato IFC $2 \times 3$. lo spazio (mostra) reale. I pannelli espositivi su cui sono stati appesi i poster sono stati modellati (fig. 4), mentre le singole tavole sono state arricchite delle informazioni inerenti all'elaborato grafico (fig. 5), oltre che ovviamente texturizzate con le immagini digitali delle impaginazioni precedentemente andate in stampa in grande formato (fig. 6).

La modellazione ha preso in considerazione l'area inerente allo 'spazio mostra' (fig. 7), ma dato che il luogo (fisico) in cui è ospitata è caratterizzato da ambienti curvi, con aule vetrate e corti interne, lo spazio realmente modellato è più vasto di quello strettamente occupato dall'esposizione, per colmare gli spazi altrimenti 'vuoti' dati proprio da mancanza
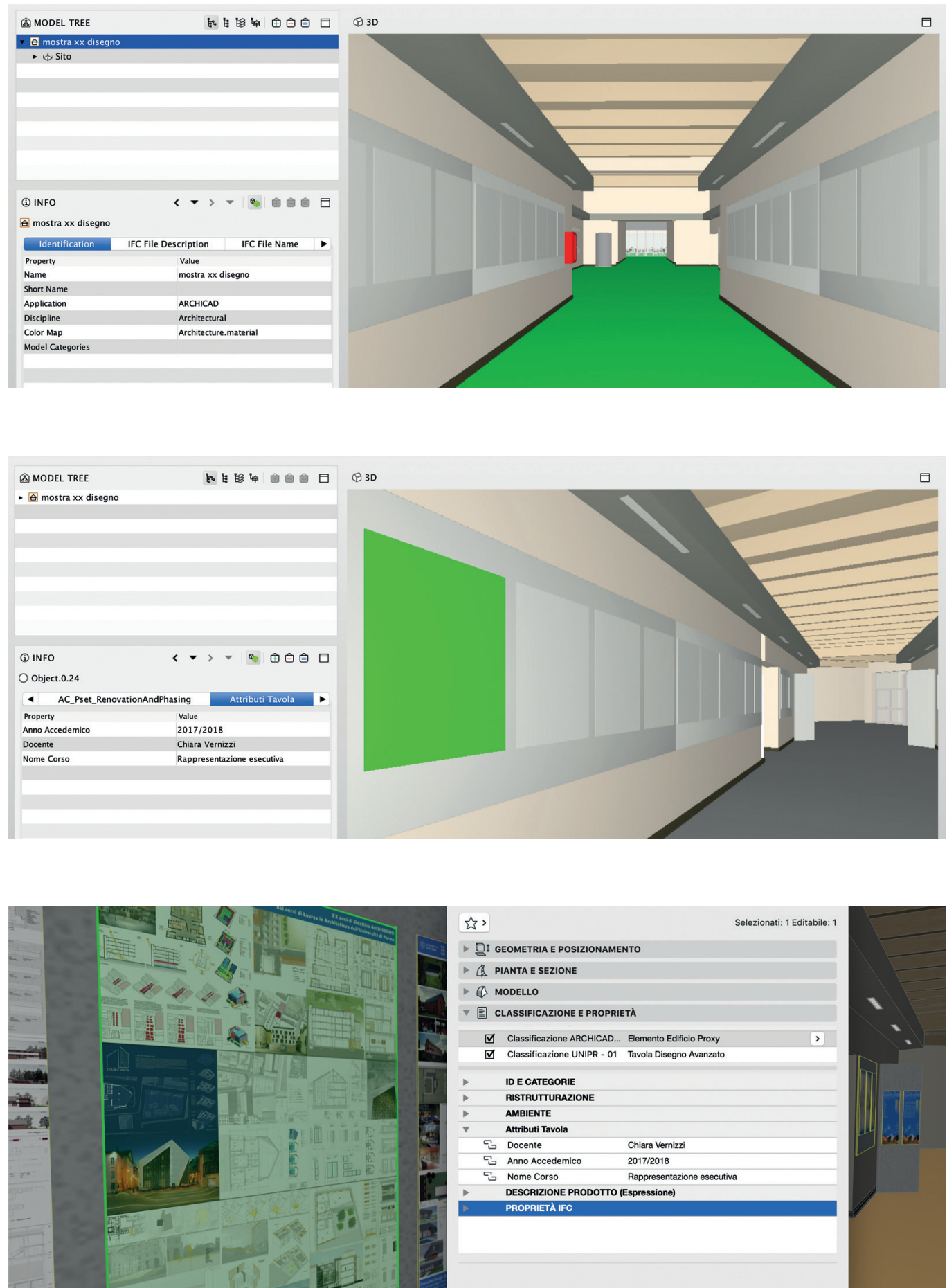


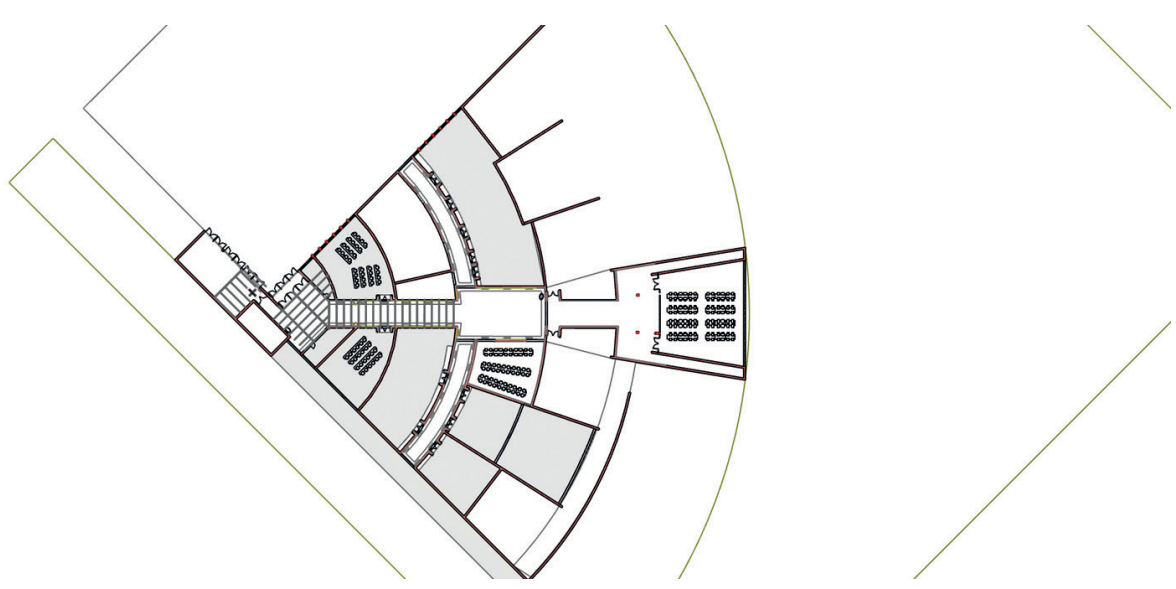

di informazioni negli scorci dei diversi punti di vista navigabili all'interno del modello. Già in questa prima fase è stata creata tramite un model-viewer una anteprima di navigazione esterna al software di modelling, verificando eventuali problemi legati alla geometria ed alle texture applicate.

In maniera omologa alla progettazione con metodologia BIM, anche in questo caso si è definita la finalità della modellazione, cioè la comunicazione dello spazio/mostra e degli elaborati esposti, così come realmente posizionati (fig. 8). Per questo motivo è stato scelto di non rappresentare elementi riguardanti impianti di raffrescamento o riscaldamento o corpi illuminanti, concentrando l'attenzione del visitatore virtuale verso gli elaborati esposti (fig. I0). Come per la 'sottile linea' che collega l'evoluzione tecnica e grafica nella sintesi degli elaborati esposti, allo stesso modo anche per questo procedimento l'attività è avanzata in evoluzione. II modello 3D realizzato all'interno di un primo programma di modellazione è stato rielaborato all'interno di un programma dedicato per la realizzazione di immagini renderizzate, per poter meglio divulgare l'idea nativa (fig. 8). La creazione dei render è stata impostata perseguendo la finalità di formare immagini 'navigabili', in questo caso utilizzando la tecnica delle 'immagini sferiche'.

Le immagini sferiche (note anche come immagini a $360^{\circ}$, mondi virtuali o pianeti virtuali) sono immagini statiche deformate. Le immagini sferiche possono nascere da una serie di fotografie realizzate da una macchina fotografica comune, combinate opportunamente con appositi software di fotoritocco, oppure da macchine fotografiche con lente convessa grandangolare. Le macchine fotografiche odierne dedicate per questo tipo di fotografia nascono con doppia ottica (fronte e retro) con lente convessa, in modo da realizzare con un singolo scatto l'immagine già deformata e unita, senza bisogno di una post-produzione per l'unione. Avendo realizzato un modello dello spazio, tale attività in questo caso è stata gestita interamente dal programma di renderizzazione, il quale, allo stesso modo delle macchine fotografiche a doppia lente, ha prodotto le immagini già opportunamente deformate e unite, una per ogni singolo punto di vista.

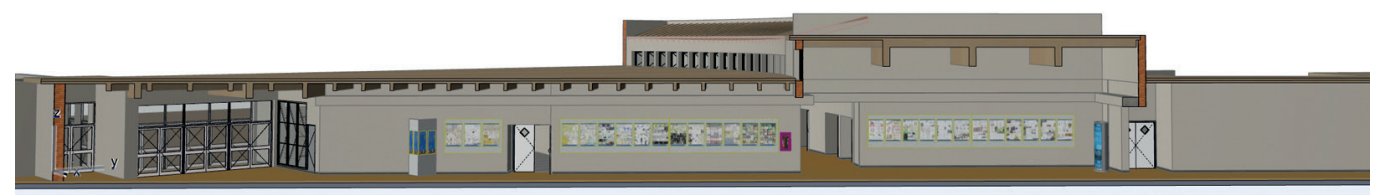


Fig. 9. Spaccato

prospettico verticale, dettaglio ravvicinato, immagine del modello dal programma di BIM Authoring.

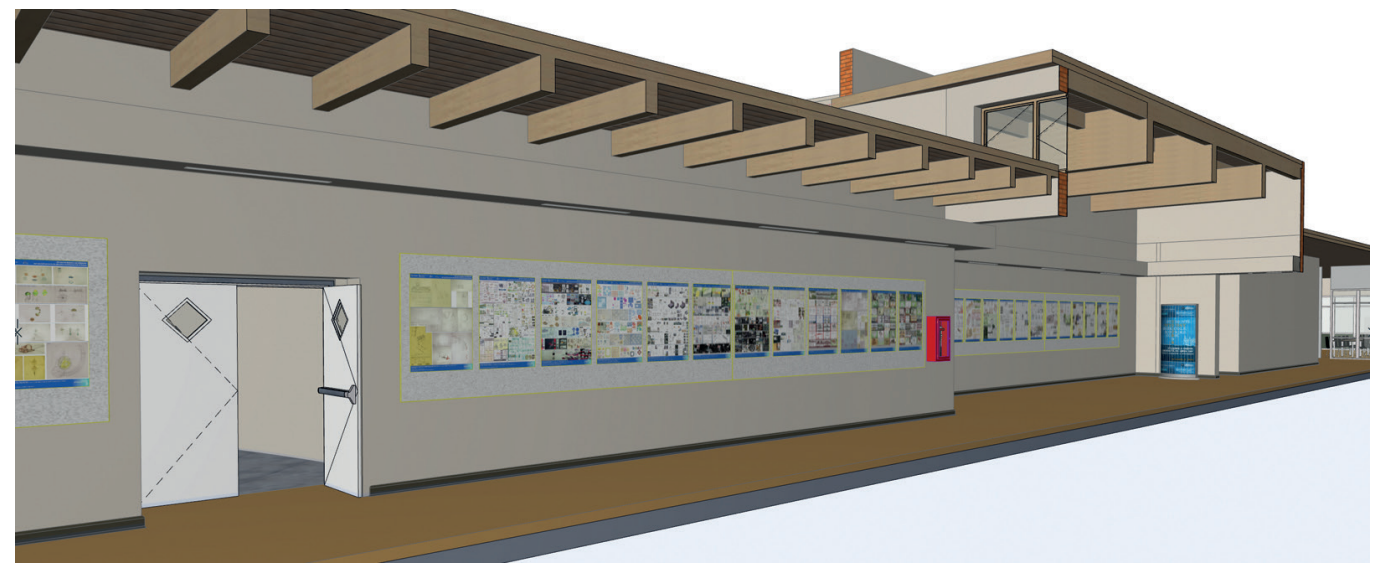

Per poterle visualizzare in maniera corretta, le 'immagini deformate' devono essere applicate all'interno di "mondi" in cui l'utente finale, posizionato al centro della sfera, abbia la possibilità di ruotare lo sguardo, mantenendo una posizione fissa. La rotazione dell'asse visivo a $360^{\circ}$ consente così di comprendere meglio ambienti e dettagli. Le immagini sferiche possono essere visualizzate tramite differenti tecnologie, come ad esempio uno spherical viewer, social network, pagine web, etc.

Sono state create ventisei immagini sferiche ad alta definizione (8K), poi concatenate formando quel 'percorso virtuale' che il visitatore avrebbe dovuto seguire nella mostra fisica (figura di copertina). All'interno dei ventisei 'mondi' implementati nel visualizzatore, è stato altresì possibile caricare altre informazioni testuali. Per migliorare a visibilità delle singole tavole esposte, è stato creato per ognuna un marker per poterne visualizzare un ingrandimento.

Per poter riunire in un unico spazio le elaborazioni prodotte, è stata creata una pagina web apposita (<http://xxdidadis.uniprit/index.html $>$ ) in cui sono inserite le informazioni sulla mostra, la parte del virtual tour, e i credits con l'elenco dei docenti che negli anni hanno contribuito, all'interno dei singoli corsi, alla realizzazione degli elaborati da parte degli studenti, in parte riassunti nelle grafiche create.

La volontà di dare vita al sito web è nata dalla necessità di testimoniare la realizzazione della mostra attraverso un luogo virtuale (fig. I I). Lo spazio web avrà la possibilità di essere utilizzato in questo modo come mostra digitale permanente, dandole la possibilità di essere fruita anche una volta che lo spazio reale sarà riallestito per altre diverse esposizioni.

Da questo punto di vista, il 'non luogo' affronta e risolve i quesiti odierni legati alla difficoltà di spostamento ed al tempo destinato all'esposizione reale (fig. 12). Questa modalità di proporre una mostra così concepita, cioè generata dalla rielaborazione di prodotti digitali nati dalla cattura di elaborati cartacei, porta alla dematerializzazione di luoghi fisici ed al superamento delle problematiche legate a trasporti e date.

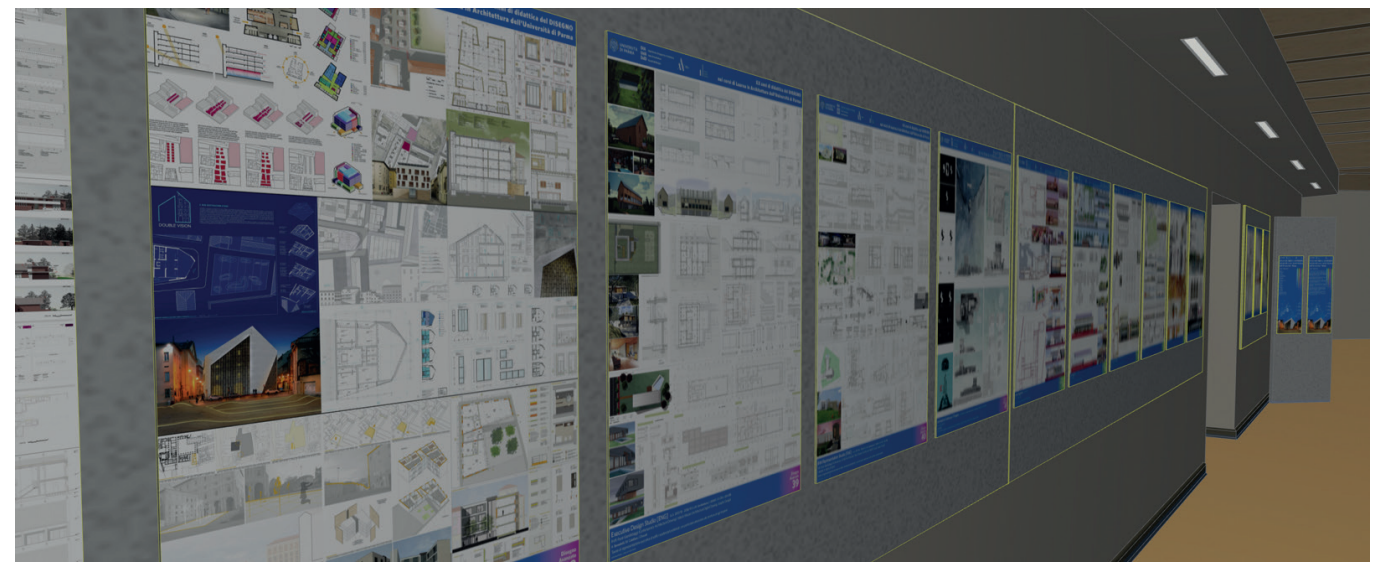

Fig. 10. Modello BIM, personalizzazione

texture inserite in fase $d$ modellazione ambiente virtuale. 
Sicuramente una soluzione simile non è applicabile a qualsiasi tipo di evento espositivo, sia per le tematiche pratiche legate alla trasmissione dei dati, sia alle tematiche emotive che la vista dal vivo delle opere porta con sé. Difficilmente tramite la visione mediata da un monitor sarà mai replicabile l'emozione che sorge guardando un dipinto impressionista o uno schizzo nato dal pugno di famosi architetti. Essere al cospetto di un'opera d'arte non ha lo stesso valore che riguardarla da un libro. Ad oggi, tale canale è sicuramente da intendere come parallelo rispetto alla mostra reale, a cui però potrà portare un maggior numero di visitatori. Molti musei importanti, come ad esempio gli Uffizi di Firenze, stanno realizzando mostre virtuali per poter far accedere i visitatori alle loro gallerie ancora chiuse al pubblico. Come accennato in precedenza, è stato prodotto anche un catalogo cartaceo della mostra, il quale è stato arricchito da collegamenti al sito web tramite QR Code. II fruitore del libro avrà così la possibilità, tramite uno smartphone $\mathrm{o}$ un tablet, di proseguire l'esperienza dal cartaceo al web. La possibilità di avere un sito web 'collegato' ad un documento cartaceo aumenta la possibilità comunicativa di entrambi, in quanto i collegamenti tramite QR Code rimangono 'agganciati' agli indirizzi della pagina web stessa, mentre i contenuti possono essere aggiornati, implementati, migliorati nel tempo, anche dopo la pubblicazione della componente cartacea. Allinterno del volume sono stati inseriti i singoli collegamenti QR agli elaborati grafici delle tavole, visibili ad alta risoluzione anche al di fuori del virtual tour. La componente tecnica sfruttata per realizzare il modello tridimensionale, sviluppata nelle immagini a $360^{\circ}$ e sfociata nel sito web, ha condotto al risultato finale di un complesso intreccio di nozioni di informatica con quello che si potrebbe definire come 'sapere rappresentativo'. Spesso, la creazione di immagini tridimensionali o viste renderizzate da modelli digitali è la richiesta prioritaria dei committenti, ma il prodotto finale non rende conto di quanto lavoro intellettuale sia stato fatto per poter arrivare ad avere tali conoscenze. Come la mostra stessa testimonia, il linguaggio grafico che trasporta il messaggio deve necessariamente sorgere su conoscenze solide, senza le quali non può che esprimere solo elaborati non corretti. Tale logica è la medesima che è applicata in ambito costruttivo con la metodologia BIM: la competenza informatica non può sopperire alla non conoscenza rappresentativa.

Fig. I I. Esposizione tavole, dettaglio risoluzione grafica, render.

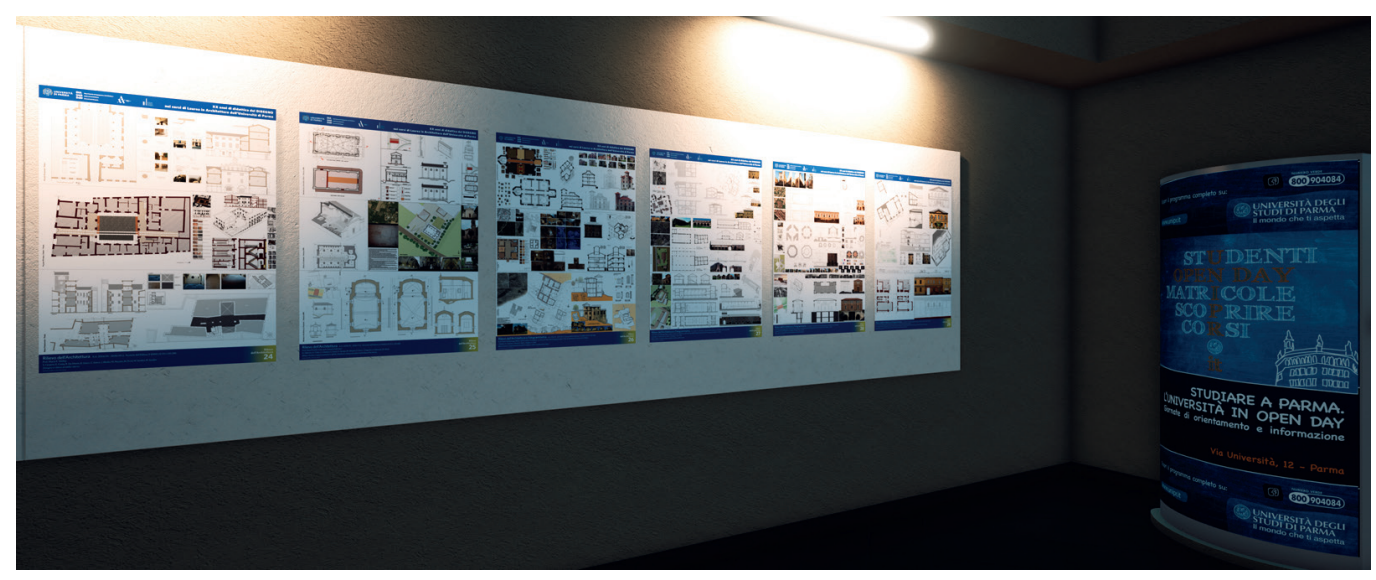

\section{Considerazioni conclusive}

Anche quelli sopra descritti sono i nostri nuovi strumenti del mestiere e, come noto, costituiscono un campo molto fertile di studio e applicazione della nostra disciplina, nel quale soprattutto i più giovani, più avvezzi e disinvolti nel controllare i nuovi strumenti digitali, si muovono con grande agio, ampliando le potenzialità e le competenze della Rappresentazione. Da tempo tutto il settore dei Beni Culturali è investito dalla Digital transformation: le tecnologie digitali stanno infatti modificando l'esperienza di visita e abilitano nuovi attrattori nei musei, mentre la rete ed i social media sono già il principale canale di accesso informativo al patrimonio culturale. 
L'evoluzione verso i media immersivi - realtà virtuale ed aumentata - sta ulteriormente accelerando la Digital transformation, abilitando modalità di fruizione innovative e iniziative di nuova concezione come le mostre virtuali senza opere fisiche, esperienze altamente coinvolgenti per il pubblico.

L'attualità del tema riguarda non riguarda solo il trovare soluzioni tecnologiche o sviluppare iniziative isolate: ad alcuni decenni dall'avvento del PC e del World Wide Web, il mondo digitale si è enormemente ampliato, sviluppando linguaggi potenti (ipermedialità, realtà virtuale, contenuti partecipativi) e industrie culturali native, come quelle dei videogame e dei social media. Ora siamo prossimi all'avvento del web 3.0, con applicazioni web AR e webVR. Le grandi piattaforme digitali ci hanno insegnato una regola chiave: porre l'utente al centro. L'esperienza culturale sta diventando immersiva e investe le persone prima, durante e dopo la visita delle mostre e dei musei. Anche nella fase di visita in presenza, il digitale sta diventando sempre più rilevante: fornisce guide aumentate, permette esperienze immersive. Nessuno di questi passaggi deve sfuggire all'operatore che sta sviluppando una strategia digitale integrata.

La piccola esperienza avviata a Parma ci ha confermato la velocità con la quale il digitale evolve e costringe a costanti aggiornamenti e adattamenti, ma anche le grandi potenzialità di questi strumenti che pur non potendosi sostituire alla ricchezza dell'esperienza reale, costituiscono un potente strumento di condivisione di esperienze e materiali.

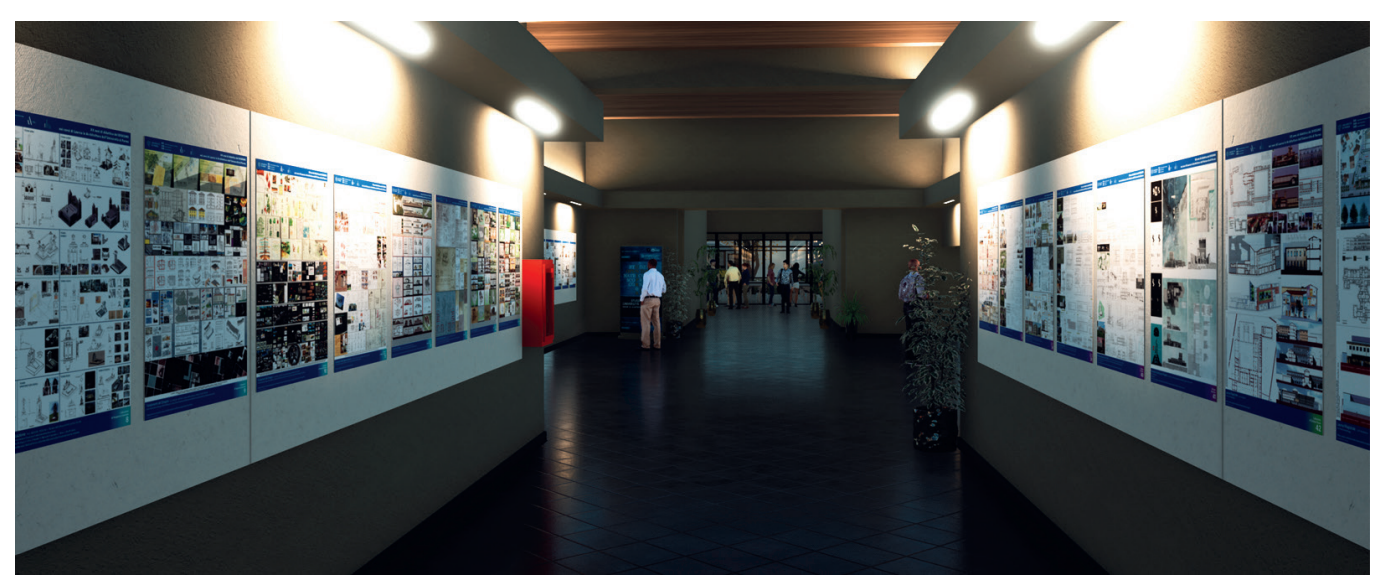

\section{Riferimenti bibliografici}

Antinozzi S., Ronchi D., Barba S., (2020). Macro e micro fotogrammetria per la virtualizzazione della laminetta orfica (V-IV a.C.) del Museo Nazionale di Vibo Valentia Macro and Micro Photogrammetry for the Virtualization of the Orphic Foil (V-IV B.C.) of National Museum of Vibo Valentia In Arena A. et al. (a cura di). Connettere. Un disegno per annodare e tessere. Atti del $42^{\circ}$ Convegno Internazionale dei Docenti delle Discipline della Rappresentazione/Connecting. Drawing for weaving relationships. Proceedings of the 42th International Conference of Representation Disciplines Teachers, pp. I538- I557. Milano: Franco Angeli.

Antonino D., Aiello A., Santagati C., (2020). Preservare la memoria: dal rilievo digitale alla realtà virtuale per la conservazione del patrimonio naturale a rischio Preserving Memory: from Digital Survey to Virtual Reality for the Conservation of Natural Heritage at Risk. In Arena A. et al. (a cura di). Connettere. Un disegno per annodare e tessere. Atti del $42^{\circ}$ Convegno Internazionale dei Docenti delle Discipline della Rappresentazione/Connecting. Drawing for weaving relationships. Proceedings of the 42th International Conference of Representation Disciplines Teachers, pp. 15 10- 1517. Milano: FrancoAngeli.

Arena A. et al. (2020). Connettere. Un disegno per annodare e tessere. Atti del $42^{\circ}$ Convegno Internazionale dei Docenti delle Discipline della Rappresentazione/Connecting. Drawing for weaving relationships. Proceedings of the 42th International Conference of Representation Disciplines Teachers. Milano: FrancoAngeli.

Bonacasa N. (20I I). II museo on line. Nuove prospettive per la museologia. Vol. I. Palermo: Collana Digitalia, Osservatorio per le Arti Decorative in Italia "Maria Accasciana".

Galizia M. et al. (2020). Connessioni tra museo/archivi e città: strategie digitali per la valorizzazione e comunicazione del fondo Fichera del Museo della Rappresentazione Museum/Archives and City Connections: Digital Strategies for the Valorization and Divulgation of the Fichera Archive of the Museo della Rappresentazione. In Arena A. et al. (a cura di). Connettere. Un disegno per annodare e tessere. Atti del $42^{\circ}$ Convegno Internazionale dei Docenti delle Discipline della Rappresentazione/Connecting. Drawing for weaving relationships. Proceedings of the 42th International Conference of Representation Disciplines Teachers, pp. 2224-2241. Milano: FrancoAngeli. 
Medici M., Ferrari F., (2020). Rilievo e documentazione del museo Tesla a Zagabria per la valorizzazione mediante applicazioni di AR e VR Survey and Documentation of the Tesla Museum in Zagreb for the Valorization through AR and VR Applications. In Arena A. et al. (a cura di). Connettere. Un disegno per annodare e tessere. Atti del $42^{\circ}$ Convegno Internazionale dei Docenti delle Discipline della Rappresentazione/Connecting. Drawing for weaving relationships. Proceedings of the 42th International Conference of Representation Disciplines Teachers, pp. 24I 4-2433. Milano: FrancoAngeli.

Quattrini R. P. et al. (2020). La Pinacoteca Civica F. Podesti di Ancona: un laboratorio didattico per la digitalizzazione del Patrimonio The Civic Art Gallery of Ancona: an Educational Laboratory for the Digitization of Cultural Heritage. In Arena A. et al. (a cura di). Connettere. Un disegno per annodare e tessere. Atti del $42^{\circ}$ Convegno Internazionale dei Docenti delle Discipline della Rappresentazione/Connecting. Drawing for weaving relationships. Proceedings of the 42th International Conference of Representation Disciplines Teachers, pp. 1974- 1993. Milano: FrancoAngeli.

Vernizzi C., Zerbi A., Bontempi D. (a cura di). (2020). XX anni di didattica del Disegno nei Corsi di Laurea in Architettura dell'Università di Parma.Vol. III, collana MADlab, Roma: Edizioni Quasar di S. Tognon s.r.l.

<http://www.otebac.it/index.php?it/320/mostre-virtuali-online-linee-guida-per-la-realizzazione> (consultato il I5 maggio 202 I).

\section{Autori}

Chiara Vernizzi, Università degli Studi di Parma, chiara.vernizzi@uniprit Roberto Mazzi, Università degli Studi di Parma, roberto.mazzi@unipr.it

Per citare questo capitolo: Vernizzi Chiara, Mazzi Roberto (2021). Dal reale al virtuale: quando la tecnologia accorcia le distanze/From Real to Virtual: when Technology Shortens Distances. In Arena A. Arena M. Mediati D. Raffa P. (a cura di) Connettere Un disegno per annodare e tessere. Linguaggi Distanze Tecnologie. Atti del $42^{\circ}$ Convegno Internozionale dei Docenti delle Discipline dello RoppresentazionelConnecting Drowing for weLining relationship. FrancoAngeli, pp. 2704-2721. 


\title{
From Real to Virtual: when Technology Shortens Distances
}

\author{
Chiara Vernizzi \\ Roberto Mazzi
}

Abstract

To celebrate the first twenty years of study courses in Architecture, in spring of 2020 an exhibition was set up at the University of Parma to show a selection of graphic designs created by the students in the various Drawing courses. The well-known pandemic events have not allowed the opening and live enjoyment of the exposition, inspiring us to create a virtual version that can be visited remotely, using modelling and visualization tools and techniques typical of architectural planning. These are increasingly focused to new needs of representation of the contents, such as the dissemination and sharing of cultural heritage.

Through the creation of the website, on which the digital parametric model of the exhibition space was uploaded and virtually set up with the same panels displayed in the physical version of the exhibition, it was possible to recreate the architectural spaces and dispose the individual posters. The virtual tour was created using, among others, the technique of spherical images.

From a negative contingency, the need arose to find other ways of distribution of the results of the work and to experiment with new ways of representation and communication of an exhibition, which was not designed to be viewed in this way. The techniques used, however, revealed their potential in increasing the fruition of the exposition without limits of time and space.

Keywords

exhibition, drawing, BIM modelling, spherical photos, virtual tour.

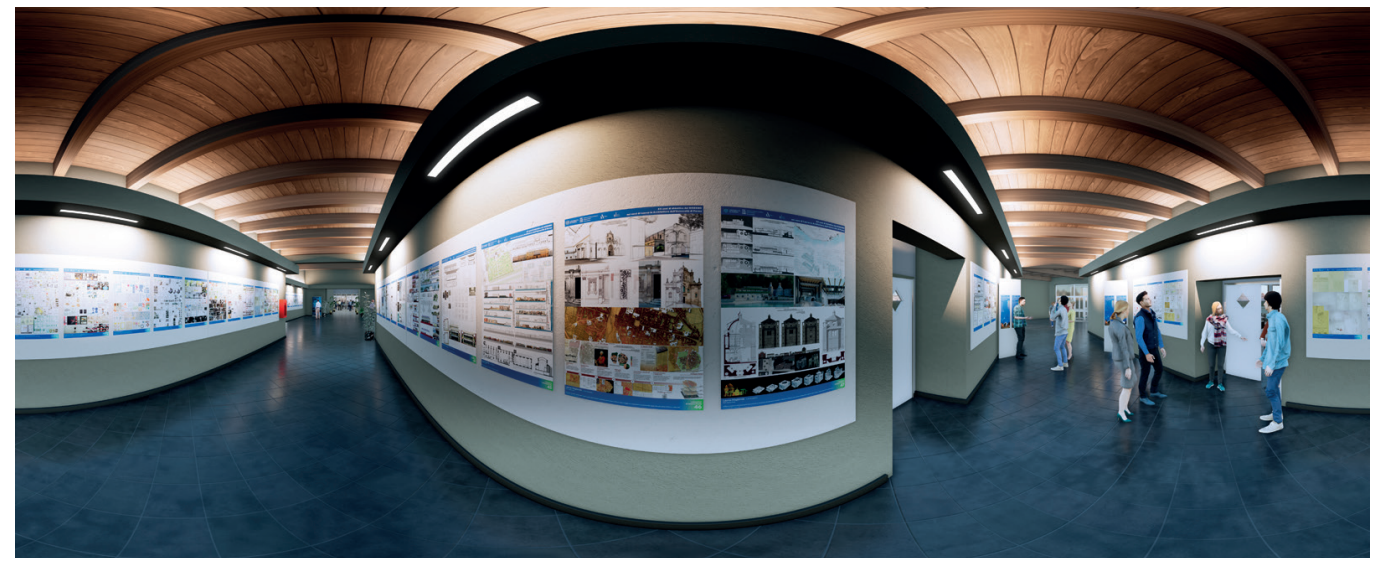




\section{Introduction}

In the spring of 2020, to celebrate the first twenty years of the degree courses in Architecture at the University of Parma (A.Y. 1999/2000 - A.Y. 2019/2020), the professors of Drawing and Survey of the Department of Engineering and Architecture promoted an exhibition aimed at showing a selection of the most significant examples of the graphic drawings made, within the teaching of the Representation area, by all the Bachelor and Master students during these twenty years.

The exhibition, sponsored by UID - Unione Italiana del Disegno as evidence of the connotation of the discipline within the Parma degree courses, was set up in the exhibition space inside the Plexus Aule delle Scienze in the University Campus of Parma. It was supposed to be inaugurated in early March at the presence of the UID Technical Scientific Committee, which for the occasion would have met in Parma.

As known, the national lockdown following the health emergency took place in early March 2020 and the exhibition, also due to subsequent restrictions that prohibited crowded meetings, was never inaugurated and open to the public.

In order not to frustrate the work done and to preserve a testimony of what has been done, other media were thought of: a catalogue of the exhibition and a website connected to the book via QR code, which would provide the opportunity of viewing the tables exhibited through an interactive virtual path.

Necessarily, we are ever closer to the virtual world and to the enjoyment of online events, of which especially in this last year we have deepened the exploration of the possibilities. In fact, we decided to design a virtual tour of the exhibition, which would allow remote attendance at more visitors, without limiting the time and space of use.

The technologies used in the creation of the virtual exhibition, described below, are fully included among the characteristic tools of our discipline, with which we usually document the existing things, and we represent the project. By virtue of their versatility, they are also adequate in the construction of this path (fig. I).

\section{Real spaces and virtual spaces}

Creating an exhibition means summarizing the issues that you want to communicate. If these themes pass through a period of twenty years, the means that carries the message must be particularly effective. Taking care of a project of an exhibition that deals with Representation and Drawing in its various aspects becomes at the same time communication tool and message.

The exhibition follows the evolution of a historical period in which the techniques of representation of the project have changed, evolved, refined. If we had to describe the pro-

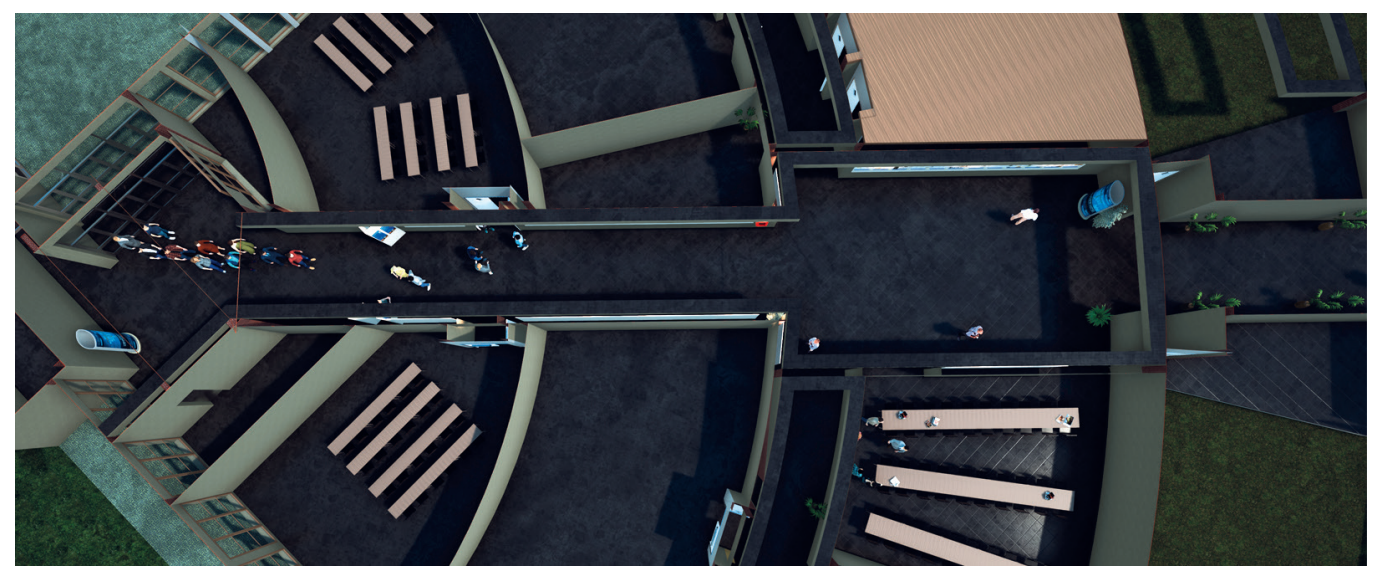


Fig. 2. Central atrium of Plexus Aule delle Scienze. reverse shot of the entrance, render.

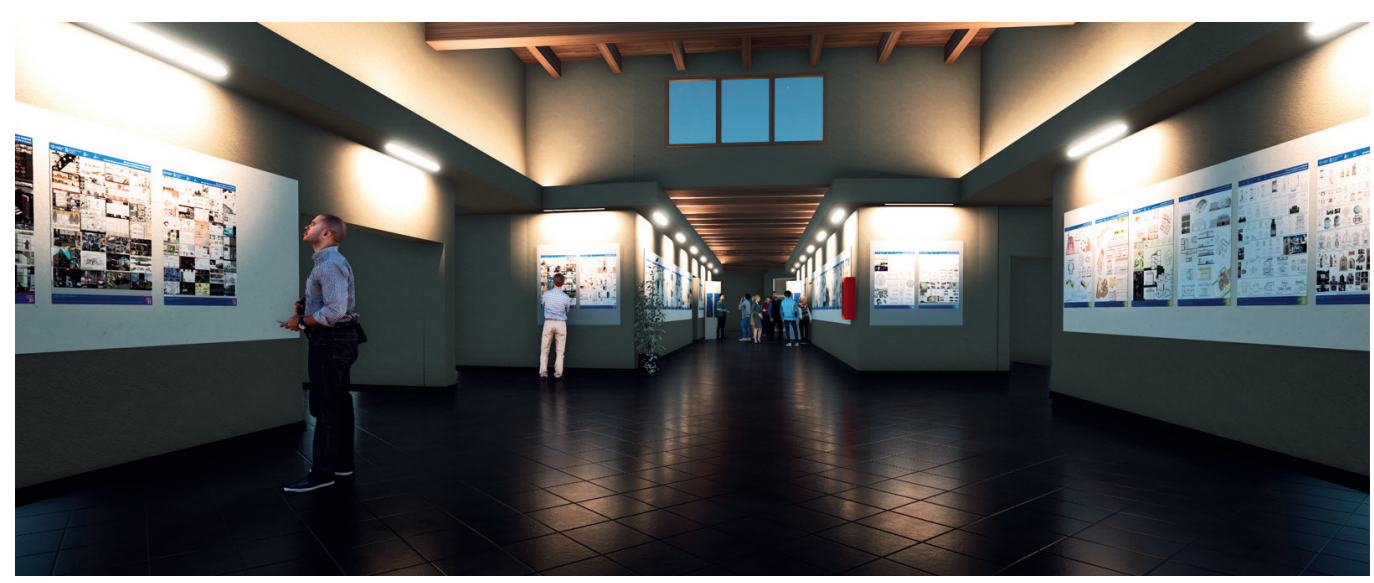

gression of the techniques used, we could represent them with an exponential curve. The collaborative logic given by the advent of information technology has seen the techniques of representation losing the characteristics given by the hand of the designer, moving towards the reproducibility given by the mouse.

These tools have been increasingly defined, while maintaining the purpose of transmission through a 'storytelling' made up of words, lines, concepts, and processes. Also for this exhibition, no exception was made to these cornerstones, starting from a project linked to the graphic design of the drawings.

Due to the new conditions imposed by the lockdown, the communicative approach and dissemination of the contents had to look in different directions. From a contingent need dictated by the emergency, we have taken the opportunity to exploit known techniques in the field of architectural design, applying them in the context of the exposition. The methods to flow the exhibition 'out of itself' could have been different, such as a series of photographs, a video, etc., but all these hypotheses involved the problem of entering a real physical place to which access was forbidden.

It was therefore decided to give a solution to this problem, by drawing from today's techniques of projects communication. In the days following the non-opening, a virtual model of the plexus was created, combining geometric information retrieved from floor plans and photographs of the rooms. The model was developed with the aim of showing the fifty posters exposed within the central corridor of the building (fig. 2).

The digital twin of the exhibition was carried out with the methods of BIM (fig. 3), by inserting the objects of the real (exhibition) space into the virtual (architectural) space thus reconstructed. The panels on which the posters were hung were modelled (fig. 4), while the single boards have been enriched with information relating to the graphic elaboration (fig. 5), as

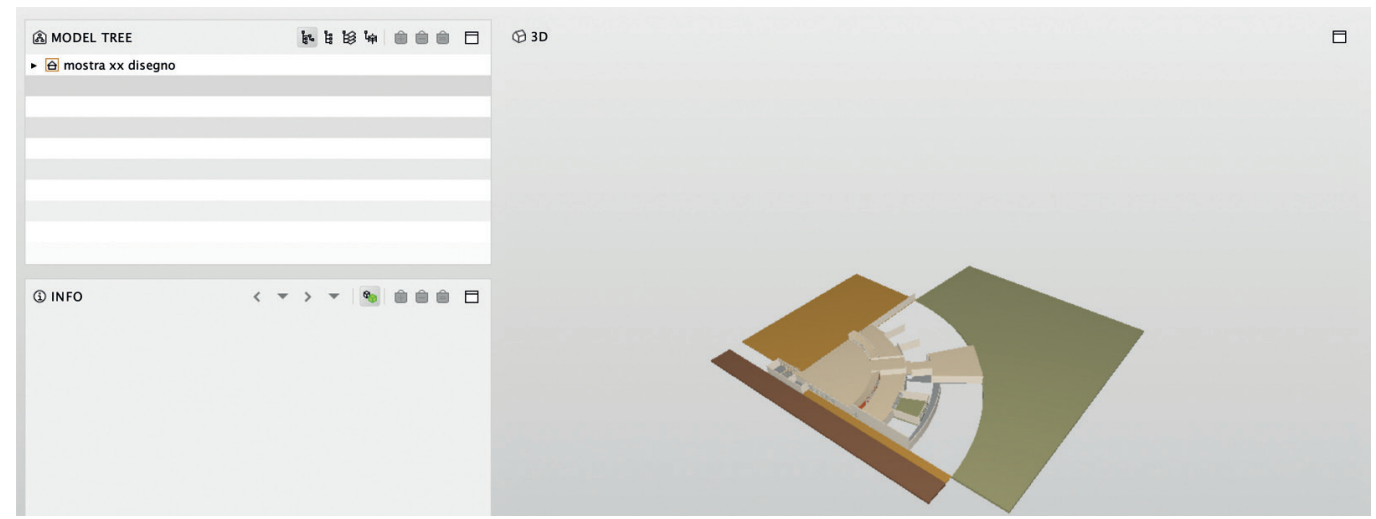


Fig. 4. BIM model, central corridor view, result of the exportation of mode in IFC $2 \times 3$ format.

Fig. 5. BIM model, information exported in the model in IFC $2 \times 3$ format. well as obviously texturized with the digital images of the layouts previously printed in large format (fig. 6).

The modelling involved the area inherent to the 'exhibition space' (fig. 7), but since the physical place in which it is housed is characterized by curved walls, with glazed classrooms and internal courtyards, the space actually modelled it is larger than the one strictly occupied by the exposition, to fill the otherwise 'empty' spaces given by the lack of information in the glimpses of the different points of view that can be navigated within the model. Already in this first phase, a preview of navigation was created using a model-view-
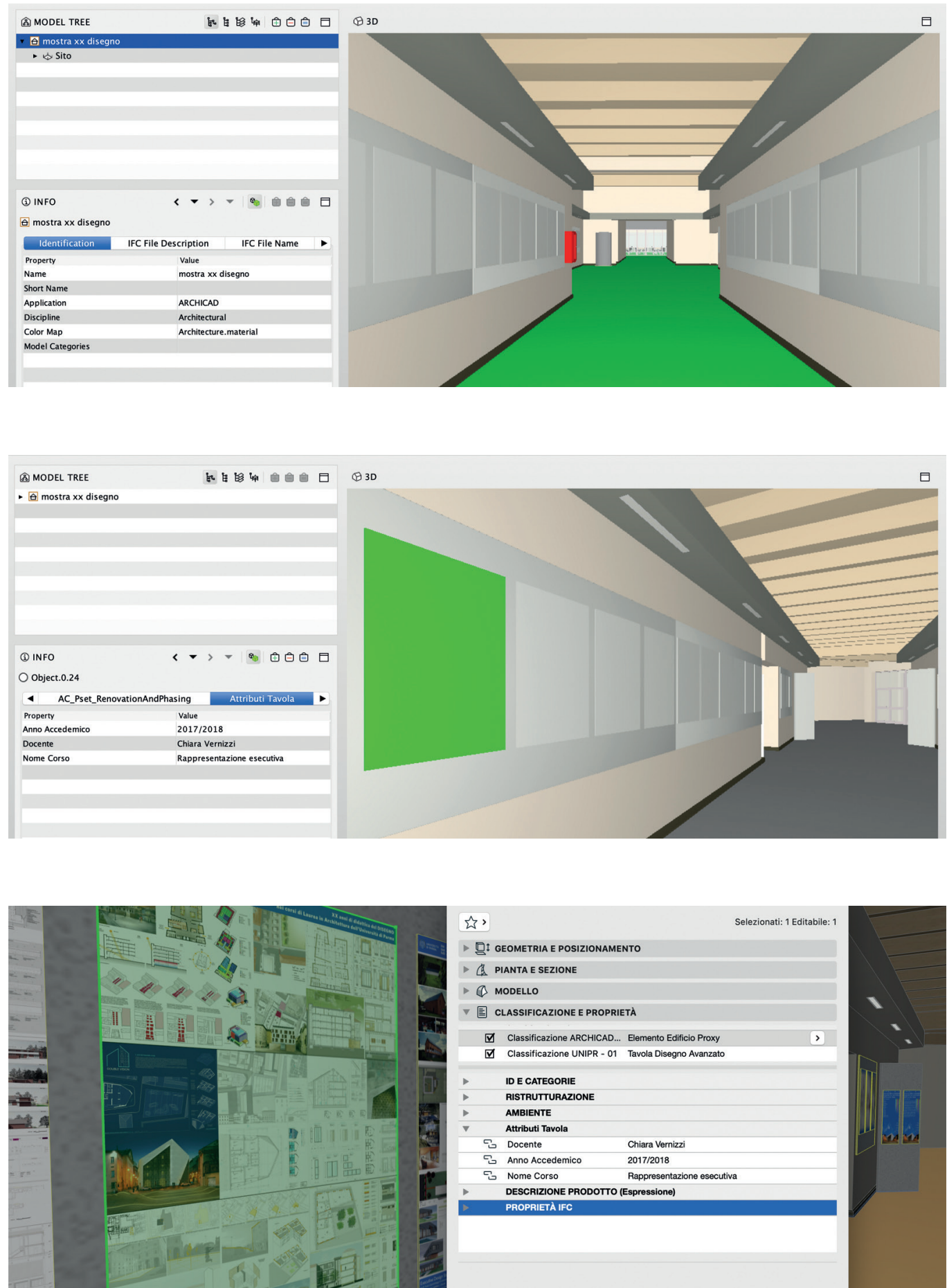
Fig. 7. Planimetry of the model in BIM Authoring software.
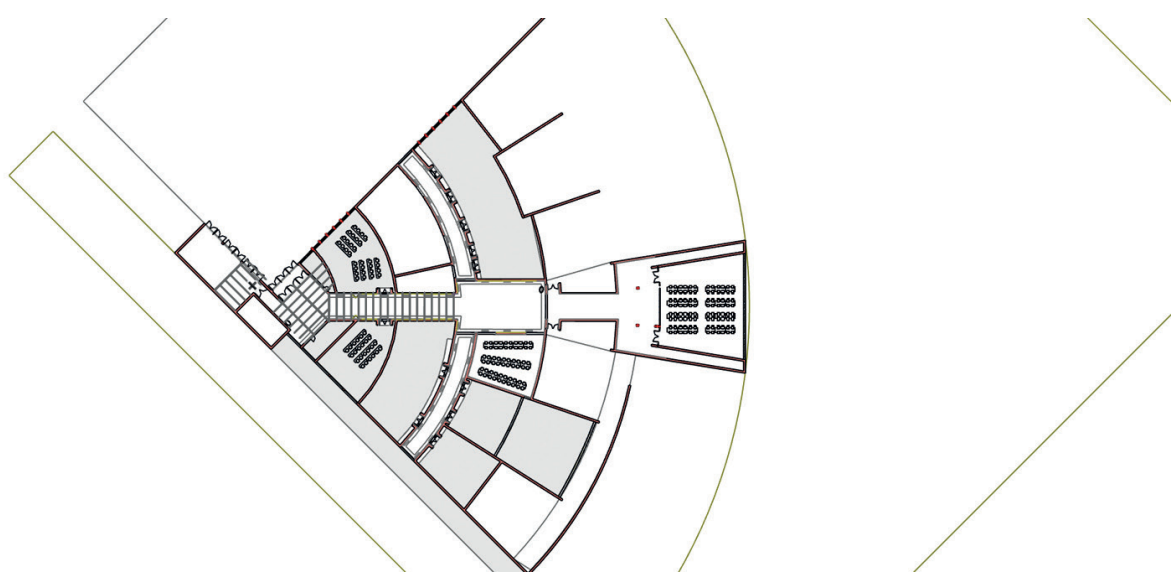

er external to the modelling software, to check any problems related to the geometry and textures applied.

In a way that is homologous to the design with BIM methodology, also in this case the purpose of the modelling has been defined, that is, the communication of the space of the exhibition and of their subjects, as they are actually positioned (fig. 8). For this reason, it was chosen not to represent elements concerning cooling or heating systems or lighting fixtures, to better focus the virtual visitor's attention on the works on display (fig. I0).

As for the 'thin line' that connects the technical and graphic evolution in the synthesis of the panels, in the same way also for this procedure the activity proceeded in evolution. The 3D model realized within a first modelling platform has been reworked within a software dedicated to the creation of rendered images, in order to better disclose the native idea (fig. 8). The creation of the renderings has been set up with the aim of forming 'navigable' images, in this case using the technique of 'spherical images'.

Spherical images (also known as $360^{\circ}$ images, virtual worlds, or virtual planets) are deformed static images. Spherical images can arise from a series of photographs taken by an ordinary camera, suitably combined with appropriate photo editing software, or by cameras with a wide-angle convex lens. Today's cameras dedicated to this type of photography are born with dual optics (front and back) with convex lens, to achieve the deformed and united image with a single click, without the need for a post-production. Working entirely in virtual space, this procedure was entirely handled by the rendering program, which, in the same way as the twin-lens camera, produced the images already deformed and joined, one for each single point of view.

To display them correctly, the 'deformed images' must be applied inside 'worlds' in which the end user, positioned in the centre of the sphere, will be able to rotate his gaze, maintaining a fixed position. The $360^{\circ}$ rotation of the visual axis allows a better understanding of environments and details. The spherical images can be viewed through different technologies, such as a spherical viewer, social networks, web pages, etc.

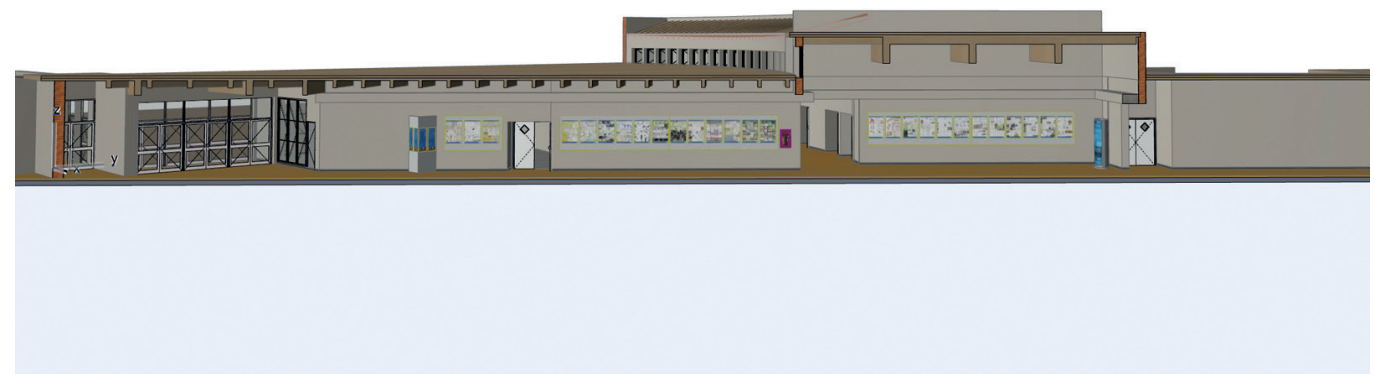


Fig. 9. Vertical perspective cross-section, close-up detail, model in BIM Authoring software.

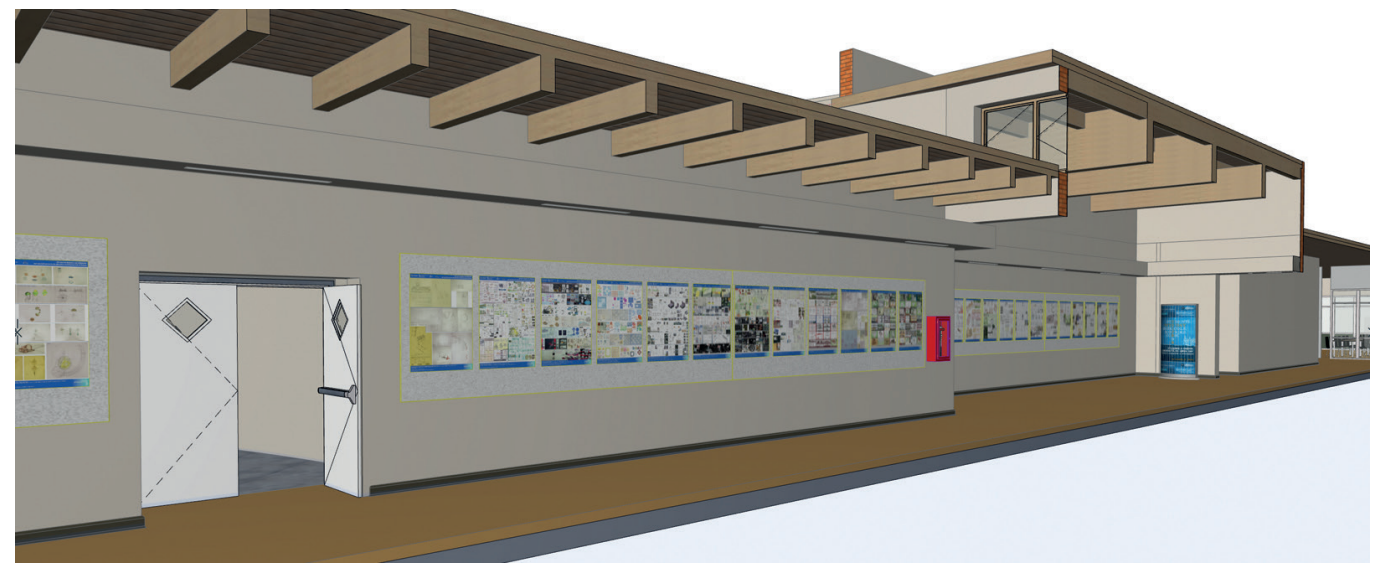

Twenty-six high definition (8K) spherical images were created, then concatenated to form the 'virtual path' that the visitor should have followed in the real exhibition (cover figure). Within the twenty-six 'worlds' implemented in the viewer, it was also possible to load other textual information. To improve the visibility of the individual boards exposed, a marker has been created for each one to access to their full resolution magnification.

To bring together in a single space the elaborations produced, a dedicated web page has been created (<http://xxdidadis.unipr.it/index.html >) that contains the general information, the virtual tour and the credits with the list of teachers who have contributed over the years, within their individual courses, to the realization of the works by the students, partly summarized in the posters.

The desire to give life to the website arose from the need to witness the realization of the exhibition through a virtual place (fig. II). The web platform will have the possibility to be used as a permanent digital exhibition, giving it the opportunity to be enjoyed even once the real space will be rearranged for other different displays.

From this point of view, the 'non-place' addresses and solves today's questions related to the difficulty of moving and the time allocated to real exposure (fig. 12). This mode of proposing an exhibition conceived in this way, that is generated by the re-elaboration of digital products born from the capture of paper documents, leads to the dematerialization of physical locations and to the overcoming of problems related to transport and dates.

Surely, a similar method is not applicable to any type of event, both for the practical issues related to data transmission, and for the emotional issues that the live view of the artworks brings with it. Hardly, the emotion that you can feel when looking at an impressionist paint-

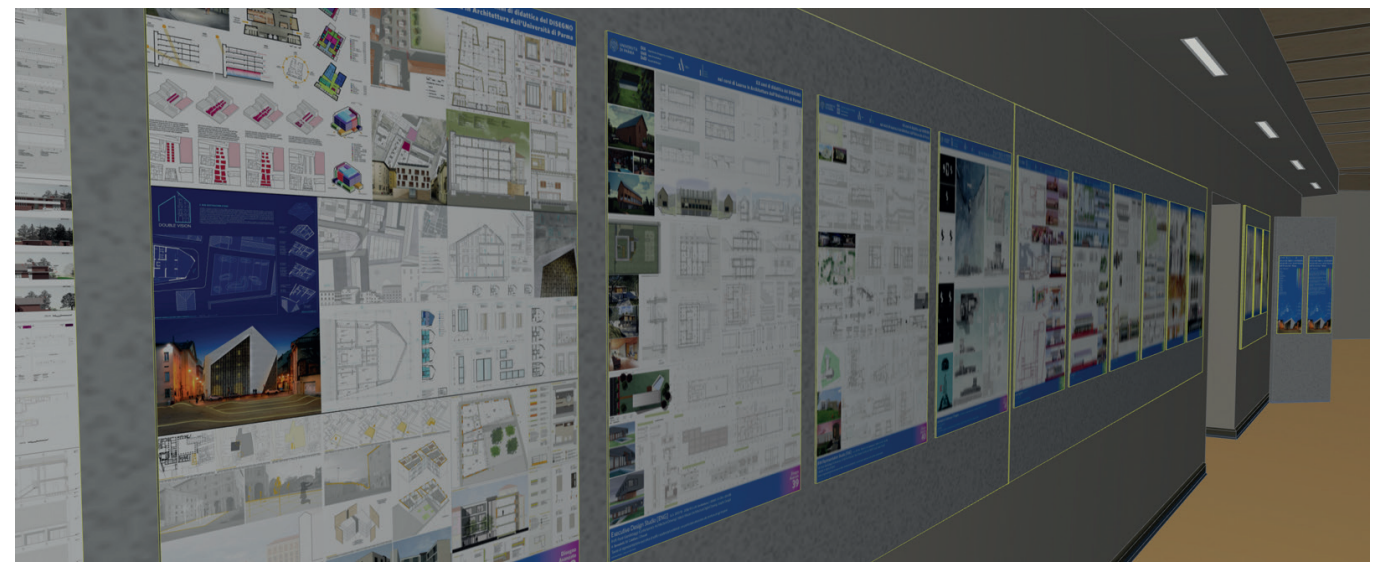


ing or a sketch created by the hand of a famous architect will ever be replicated through the mediated vision of a monitor. Being in the presence of a work of art does not have the same value as looking at it on a book. Today, such a channel is certainly to be conceived as parallel to the real exhibition, to which, however, it will bring a greater number of visitors. Many major museums, such as the Uffizi in Florence, are opening virtual exhibitions to allow the visitors to access their galleries that are still closed to the public.

As previously mentioned, a printed catalogue of the exhibition was also produced, which was enriched by links to the website via QR Code. The book reader will thus have the opportunity, via smartphone or tablet, to continue the experience from paper to the web. The possibility of having a website 'linked' to a paper document enhances the communication possibilities of both, as the links via QR Code remain 'hooked' to the addresses of the web page itself, while the contents can be updated, implemented, improved in time, even after the publication of the book. Inside the volume, the individual QR links to the drawings have been inserted, which are visible at high resolution even outside the virtual tour.

The technical component used to carry out the three-dimensional model, developed in the $360^{\circ}$ images and finalized in the website, led to the result of a complex intertwining of computer science with what could be described as 'representative knowledge'.

Often, creating three-dimensional images or rendered views from digital models is the priority request of the clients, but the final product does not realize how much intellectual work has been done to get such knowledge. As the exhibition itself testifies, the graphic language that carries the message must necessarily come from solid knowledge, without which it can only express incorrect elaborations. This is the same logic that is applied in the construction field with BIM methodology: computer skills cannot make up for the lack of representative knowledge.

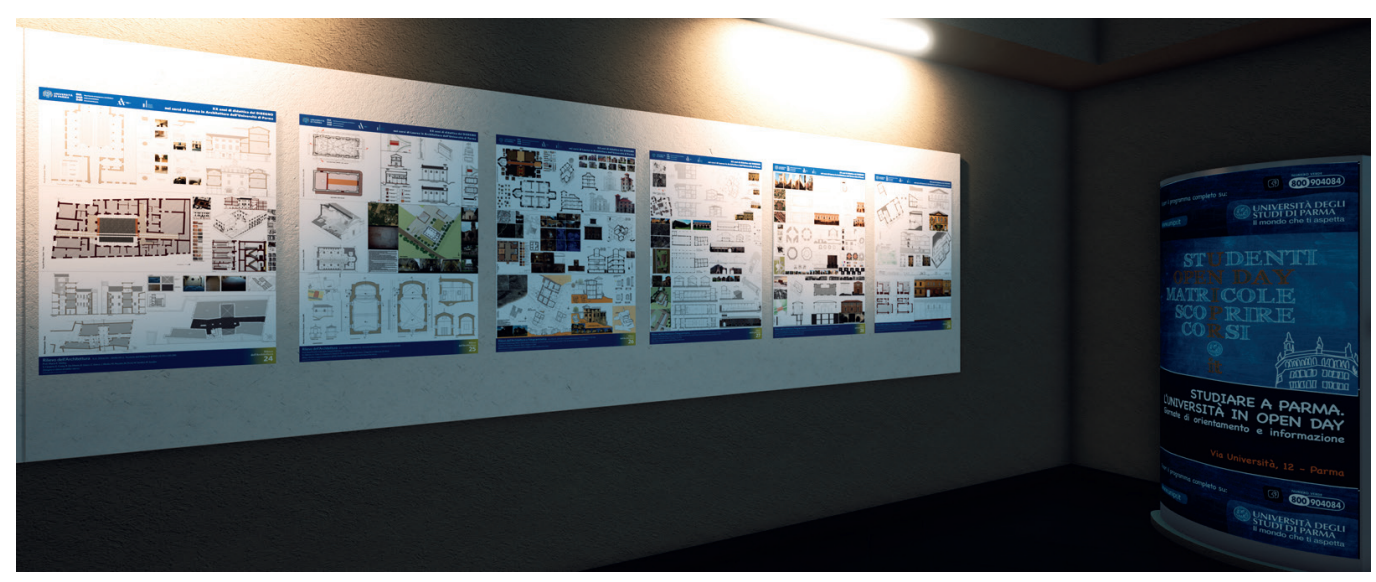

\section{Conclusion}

Our new tools of the trade include those described above. Indeed, they constitute a very fertile field of study and application of our discipline, in which especially the youngest researchers, more used and confident in controlling the new digital devices, move with great ease, expanding the potential and skills of Representation.

For some time now, the whole sector of Cultural Heritage has been invested by Digital transformation: in fact, the digital technologies are changing the visitor experience and enabling new attractors in museums, while web and social media already are the main information channel of access to cultural heritage.

The evolution towards immersive media - virtual and augmented reality- is further accelerating the Digital transformation, enabling innovative ways to use and newly conceived initiatives such as virtual exhibitions without physical objects, highly engaging experiences for the public. 
The topicality of the subject does not only concern finding technological solutions or developing isolated initiatives: few decades after the advent of the PC and the World Wide Web, the digital world has enormously expanded, developing powerful languages (hypermedia, virtual reality, participatory contents) and original cultural industries, such as videogames and social media. Now, we are close to the advent of 3.0 web, with web AR and VR applications. The largest digital platforms have taught us a key rule: to put the user at the centre. The cultural experience is becoming immersive and involves the people before, during and after enjoying the exhibitions and museums. Even during the face-to-face visit, digital is becoming more and more relevant: it provides enhanced guides, it allows immersive experiences. None of these steps should be forgotten by the operator who is developing an integrated digital strategy.

The small experience started in Parma confirmed the speed with which the digital evolves and forces constant updates and adaptations, but also it consolidated the great potential of these tools which, although they cannot replace the richness of real experience, can be a powerful instrument for sharing experiences and data.

Fig. 12. Panel exposition in the central corridor detail of graphic resolution, render.

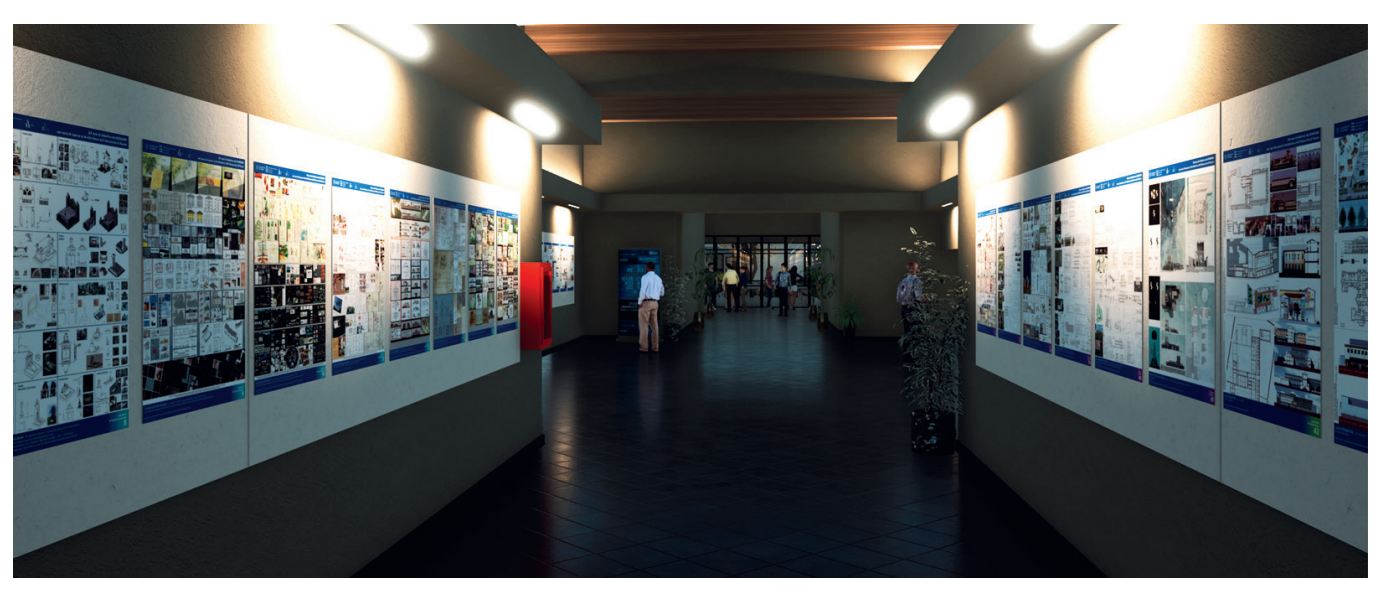

\section{References}

Antinozzi S., Ronchi D., Barba S., (2020). Macro e micro fotogrammetria per la virtualizzazione della laminetta orfica (V-IV a.C.) del Museo Nazionale di Vibo Valentia Macro and Micro Photogrammetry for the Virtualization of the Orphic Foil (V-IV B.C.) of National Museum of Vibo Valentia In Arena A. et al. (Eds.). Connettere. Un disegno per annodare e tessere. Atti del $42^{\circ}$ Convegno Internazionale dei Docenti delle Discipline della Rappresentazione/Connecting. Drawing for weaving relationships. Proceedings of the 42th International Conference of Representation Disciplines Teachers, pp. I 538- I 557. Milano: FrancoAngeli.

Antonino D., Aiello A., Santagati C., (2020). Preservare la memoria: dal rilievo digitale alla realtà virtuale per la conservazione del patrimonio naturale a rischio Preserving Memory: from Digital Survey to Virtual Reality for the Conservation of Natural Heritage at Risk. In Arena A. et al. (Eds.). Connettere. Un disegno per annodare e tessere. Atti del $42^{\circ}$ Convegno Internazionale dei Docenti delle Discipline della Rappresentazione/Connecting. Drawing for weaving relationships. Proceedings of the 42th International Conference of Representation Disciplines Teachers, pp. I5 10-1517. Milano: FrancoAngeli.

Arena A. et al. (2020). Connettere. Un disegno per annodare e tessere. Atti del $42^{\circ}$ Convegno Internazionale dei Docenti delle Discipline della Rappresentazione/Connecting. Drawing for weaving relationships. Proceedings of the 42 th International Conference of Representation Disciplines Teachers. Milano: FrancoAngeli.

Bonacasa N. (20 I I). II museo on line. Nuove prospettive per la museologia. Vol. I. Palermo: Collana Digitalia, Osservatorio per le Arti Decorative in Italia "Maria Accasciana".

Galizia M. et al. (2020). Connessioni tra museo/archivi e città: strategie digitali per la valorizzazione e comunicazione del fondo Fichera del Museo della Rappresentazione Museum/Archives and City Connections: Digital Strategies for the Valorization and Divulgation of the Fichera Archive of the Museo della Rappresentazione. In Arena A. et al. (Eds.). Connettere. Un disegno per annodare e tessere. Atti del $42^{\circ}$ Convegno Internazionale dei Docenti delle Discipline della Rappresentazione/Connecting. Drawing for weaving relationships. Proceedings of the 42th International Conference of Representation Disciplines Teachers, pp. 2224-2241. Milano: FrancoAngeli.

Medici M., Ferrari F., (2020). Rilievo e documentazione del museo Tesla a Zagabria per la valorizzazione mediante applicazioni di AR e VR Survey and Documentation of the Tesla Museum in Zagreb for the Valorization through AR and VR Applications. In Arena A et al. (Eds.). Connettere. Un disegno per annodare e tessere. Atti del $42^{\circ}$ Convegno Internazionale dei Docenti delle Discipline della Rappresentazione/Connecting. Drawing for weaving relationships. Proceedings of the 42th International Conference of Representation Disciplines Teachers, pp. 24I4-2433. Milano: FrancoAngeli. 
Quattrini R. P. et al. (2020). La Pinacoteca Civica F. Podesti di Ancona: un laboratorio didattico per la digitalizzazione del Patrimonio The Civic Art Gallery of Ancona: an Educational Laboratory for the Digitization of Cultural Heritage. In Arena A. et al. (Eds.). Connettere. Un disegno per annodare e tessere. Atti del $42^{\circ}$ Convegno Internazionale dei Docenti delle Discipline della Rappresentazione/Connecting. Drawing for weaving relationships. Proceedings of the 42th International Conference of Representation Disciplines Teachers, pp. 1974-1993. Milano: FrancoAngeli.

Vernizzi C., Zerbi A., Bontempi D. (Eds.). (2020). XX anni di didattica del Disegno nei Corsi di Laurea in Architettura dell'Università di Parma.Vol. III, collana MADlab, Roma: Edizioni Quasar di S. Tognon s.r.l.

<http://www.otebac.it/index.php?it/320/mostre-virtuali-online-linee-guida-per-la-realizzazione> (accessed 202I, May I5).

\section{Authors}

Chiara Vernizzi, Università degli Studi di Parma, chiara.vernizzi@unipr.it

Roberto Mazzi, Università degli Studi di Parma, roberto.mazzi@unipr.it

To cite this chapter: Vernizzi Chiara, Mazzi Roberto (2021). Dal reale al virtuale: quando la tecnologia accorcia le distanze/From Real to Virtual: when Technology Shortens Distances. In Arena A., Arena M., Mediati D., Raffa P. (a cura di). Connettere. Un disegno per annodare e tessere. Linguaggi Distanze Tecnologie. Atti del $42^{\circ}$ Convegno Internazionale dei Docenti delle Discipline della Rappresentazione/Connecting. Drawing for weaving relationship. Languages Distances Technologies. Proceedings of the 42th International Conference of Representation Disciplines Teachers. Milano: FrancoAngeli, pp. 2704-2721. 